Jako przewodniczący Rady Fundacji Uniwersytetu Warszawskiego doprowadził do podpisania decyzji przez premiera Tadeusza Mazowieckiego o przeznaczeniu środków $\mathrm{z}$ wynajmu gmachu PZPR na budowę Biblioteki Uniwersyteckiej. Otrzymał za to Krzyż Komandorski Orderu Polonia Restituta.

Byłczłonkiem Komitetu Nauk Prawnych PAN, Komisji Legislacyjnej przy Prezesie Rady Ministrów, Komisji Reformy Prawa Cywilnego przy Ministrze Sprawiedliwości, Rady Polityczno-Społecznej przy Prezesie Rady Ministrów.

Przez wiele lat uczestniczył w pracach kilku redakcji, w tym także w Radzie Programowej «Zeszytów Prawniczych». Dorobek naukowy i wykaz publikacji Profesora Dybowskiego został przedstawiony w zeszycie 3.2 (2003) Jemu dedykowanym w osiemdziesiątą rocznicę urodzin.

Jan Zabłocki*

\title{
ANDRZEJ KREMER
}

(1961-2010)

W katastrofie „Prezydenckiego Samolotu” zginą 10 kwietnia 2010 r. nasz Kolega i Przyjaciel dr Andrzej Kremer, prawnik, dyplomata, Podsekretarz Stanu w Ministerstwie Spraw Zagranicznych, odpowiedzialny za sprawy prawne, traktatowe i konsularne. Pozostawił żonę i trzech synów. Odznaczony pośmiertnie Krzyżem Komandorskim Orderu Odrodzenia Polski i Odznaką Honorową ‘Bene Merito' Ministra Spraw Zagranicznych spoczął 21 kwietnia br. w Alei Zasłużonych na Cmentarzu Rakowickim w Krakowie. Pogrzeb poprzedziła Msza św. żałobna w Kościele Matki Bożej Ostrobramskiej w Krakowie. Ceremonii pogrzebowej przewodniczył Metropolita Krakowski Kardynał Stanisław Dziwisz.

\footnotetext{
* Uniwersytet Kardynała Stefana Wyszyńskiego.
} 
Andrzej Kremer urodzony 8 sierpnia 1961 r. w Krakowie, absolwent II Liceum Ogólnokształcące im. Króla Jana Sobieskiego w 1984 r. ukończył studia na Wydziale Prawa i Administracji Uniwersytetu Jagiellońskiego. W 1986 r. po odbyciu aplikacji w Sądzie Wojewódzkim w Krakowie zdał egzamin sędziowski z wynikiem bardzo dobrym. W 1993 r. uzyskał stopień doktora nauk prawnych, na podstawie rozprawy „Kontrakty nienazwane w prawie rzymskim w świetle kazuistyki" napisanej w Katedrze Prawa Rzymskiego UJ, pod kierunkiem prof. dr hab. Janusza Sondla. Jeszcze w trakcie studiów został zatrudniony jako pracownik naukowy Wydziału Prawa i Administracji Uniwersytetu Jagiellońskiego w Katedrze Prawa Rzymskiego. W latach 1988-1990 był stypendystą na uniwersytetach w Getyndze i Salzburgu, a w 1989 r. także pracownikiem naukowym Katedry Prawa Rzymskiego na Uniwersytecie w Bochum. Znał łacinę, biegle władał językiem niemieckim, włoskim i rosyjskim. Był autorem wielu artykułów naukowych z zakresu prawa rzymskiego, prawa dyplomatycznego i konsularnego oraz publicznego prawa międzynarodowego.

Przygotowywał rozprawę habilitacyjną na temat „Piotr Rojzjusz jako przykład renesansowego romanisty".

Należał do tych najzdolniejszych i najlepiej wykształconych ludzi, którzy rezygnując z kariery naukowej, swoje zdolności i wiedzę poświęcili służbie państwu. Sukcesy dyplomatyczne rekompensowały Mu częściowo brak czasu, którego nie mógł wykorzystać do pracy nad rozprawą habilitacyjną.

Pracę dyplomatyczną rozpoczął 1991 r., jako Wicekonsul, potem Konsul w Konsulacie Generalnym RP w Hamburgu, następnie od 1995 r. jako Kierownik Wydziału Konsularnego Ambasady RP w Bonn, w randze radcy, a następnie radcy ministra pełnomocnego. W $1998 \mathrm{r}$. został Wicedyrektorem Departamentu Konsularnego i Wychodźstwa. a po reorganizacji Dyrektorem Departamentu Konsularnego MSZ. W 2001 r. został Konsulem Generalnym RP w Hamburgu. W 2005 r. powrócił do pracy w MSZ w Warszawie, gdzie został Ambasadorem tytularnym w służbie zagranicznej i pracował jako Zastępca, a od 2007 r. jako Dyrektor Departamentu Prawno-Traktatowego. W 2008 r. został wiceministrem Spraw Zagranicznych w randze Podsekretarza 
Stanu nadzorującym, miedzy innymi, służbę konsularną, relacje ze Wschodem oraz sprawy prawno-traktatowe. Negocjował, a później parafował polsko-amerykańskie porozumienie o stacjonowaniu wojsk amerykańskich w Polsce. Brał udział w negocjacjach nad kształtem nowego traktatu Unii Europejskiej. Był jednym z autorów programu „Partnerstwa Wschodniego" mającym na celu zacieśnienie stosunkową miedzy Unia Europejską a jej wschodnimi sąsiadami: Armenią, Azerbejdżanem, Białorusią, Gruzją, Mołdawią i Ukrainą. Pracował też na rzecz dobrych relacji miedzy Polską a jej sąsiadami, szczególnie z Rosja.

\footnotetext{
* Uniwersytet Kardynała Stefana Wyszyńskiego.
} 